\title{
Kohti monimuotoista viljelyä erikoiskasvien avulla
}

Marjo Keskitalo $^{1}$, Christian Eriksson ${ }^{2}$, Kaija Hakala ${ }^{1}$, Arsi Ikonen ${ }^{3}$, Saara Kaipainen ${ }^{4}$, Sirpa Kurppa ${ }^{3}$, Ansa Palojärvi ${ }^{4}$, Katriina Soini ${ }^{3}$, Harri Turunen ${ }^{4}$, Heli Vuorio ${ }^{3}$

${ }^{I}$ MTT Kasvintuotannon tutkimus, Kasvinviljely ja biotekniikka, 31600 Jokioinen, marjo.keskitalo@mtt.fi,kaija.hakala@mtt.fi,saara.kaipainen@mtt.fi,ansa.palojarvi@mtt.fi

${ }^{2}$ MTT Tutkimuspalvelut, Tietopalvelut,31600Jokioinen, christian.eriksson@mtt.fi

${ }^{3}$ MTT Ympäristöntutkimus, Ympäristöhallinta, 31600 Jokioinen, arsi.ikonen@mtt.fi, sirpa.kurppa@mtt.fi,katriina.soini@mtt.fi,heli.vuorio@mtt.fi,

${ }^{4}$ MTT Ympäristöntutkimus, Maaperä ja ympäristö, 31600 Jokioinen, saara.kaipainen@mtt.fi, ansa.palojarvi@mtt.fi

${ }_{5}^{5}$ MTT Taloustutkimus,_Lutnantintie 13,00410Helsinki,harri.turunen@mtt.fi

\section{Tiivistelmä}

Monimuotoisuudella tarkoitetaan pellossa elävien, siitä ravintonsa saavien tai siellä tavattavien eläin-, kasvi-, hyönteis- ja mikrobistolajien moninaisuutta. Pellon monimuotoisuuteen kuuluu myös viljelykasvien geneettinen ja lajimääräinen monimuotoisuus. Tapa jolla pellon monimuotoisuutta hoidetaan, vaikuttaa pellon yksisoluisista organismeista lähtien aina maisemaan, maaseudun elinvoimaisuuteen ja maataloustuotteiden kauppaan saakka. Eri lähteiden mukaan voidaan erottaa ainakin neljä tekijää, joilla on havaittu olevan vaikutusta monimuotoisuuteen. 1) Torjuta-aineiden vähentäminen; 2) Kevytmuokkauksen suosiminen; 3) Typpilannoituksen vähentäminen ja 4) Viljelykierrot ja viljelykasvilajiston lisääminen.

MTT:ssä vuonna 2003 alkaneessa MONIKASVI-tutkimuksessa tuotetaan monitieteellisesti tietoa erikoiskasvien avulla tapahtuvasta peltoluonnon monimuotoisuuden lisäämisestä. Tietoa tuotetaan täsmällisten viljelykierto- ja viljelykasvilajiston lisäämisen suositusten laatimiseksi. Tavoitteet ovat 1) Tuottaa tietoa neljän yksivuotisen (kinua, kitupellava, tattari ja öljypellava) ja neljän kaksi- tai monivuotisen (kumina, morsinko, nokkonen, ruokohelpi) erikoiskasvin monimuotoisuuteen vaikuttavista ominaisuuksista sekä kasvien viljelyn mikroympäristön monimuotoisuudesta; 2) Laskea valittujen erikoiskasvien viljelyn kannattavuus; 3) Selvittää viljelijöiden käsityksiä ja halukkuutta ryhtyä erikoiskasviviljelijäksi; 4) Luoda erikoiskasveille monimuotoisuusarvo, funktio, jossa kasvit erityisen hyvin monimuotoistavat peltoa; 5) Kehittää tiloille atk-pohjaista menetelmää, jolla viljelykasvit voidaan sijoittaa oikein peltolohkoille monimuotoisuuden lisäämiseksi ja ravinteiden huuhtoutumisriskin vähentämiseksi.

Erikoiskasvien viljely viljelykasvilajiston monipuolistamisessa ja osana viljelykiertoa on perusteltua. 1) Erikoiskasvit sisältävät suuren ominaisuuksien kirjon, mikä on hyvä lähtökohta pellon monimuotoisuuden edistämisessä. 2) Viljely on Suomessa laajentunut lähes satakertaisesti kymmenen viime vuoden aikana ja jo nyt erikoiskasveja viljellään tuhansilla tiloilla; 3) Erikoiskasvien viljely on maataloutta ja maaseudun yritystoimintaa aktivoivaa toimintaa; 4) Kun monimuotoisuutta ylläpidetään kuluttajaa kiinnostavien ja arvostavien 'vihreitä' hyötyaineita tuottavien erikoiskasvien avulla, saanee viljelytukien maksu suurenkin yleisön hyväksynnän; 5) Ympäristön monimuotoisuuden kannalta monimuotoista, usean viljelykasvin maataloutta harjoittavilla tiloilla on erityinen tilaus tulevaisuudessa.

Kaksisirkkaisten ja monivuotisten erikoiskasvien viljelyn lisääminen on pellon monimuotoisuuden kannalta oleellista, vaikka tutkimukset ovatkin vielä kesken. Se, miten eri kasveilla voidaan täsmällisemmin vaikuttaa eri eliöiden monimuotoisuuteen ja minkälaisissa viljelykierroissa niitä tulisi viljellä, tarvitsee lisätutkimuksia, joita Monikasvissakin tehdään. Lisätietoa tulee saada myös eri eliöiden laji- ja populaatiomäärien muutoksista, jotta viljelytoimenpiteet voitaisiin kohdistaa ainakin uhanalaisten eliöiden suojelemiseksi. Erikoiskasvien viljely monimuotoisuuden lisäksi myös ravinnehuuhtoutumisriskin vähentämiseksi tekee kokonaisuuden hallitsemisen vieläkin haasteellisemmaksi, vaikka monet toimenpiteet edesauttavat molempia ympäristöongelmia. Tämän takia on tärkeää, että menetelmiä monimuotoisuuden edistämiseksi ja ravinteiden vähentämiseksi kehitetään. Tulevaisuudessa on hyvinkin mahdollista, että voimme erikoiskasvien funktionaalisiin ominaisuuksiin ja pellon paikkatietoihin perustuen laatia kasvilajiston laajentamisesta ja viljelykierroista täsmäsuosituksia 'lääkkeeksi' pellon monimuotoisuuden edistämiseksi ja ravinnehuuhtoutumisten vähentämiseksi. 
Asiasanat monimuotoisuus, biodiversiteetti, erikoiskasvit, erikoiskasvien biologiset ominaisuudet, viljelyn kannattavuus, hyväksyttävyys, monimuotoisuuden suunnittelumenetelmä, GIS

\section{Pellon monimuotoisuuden merkitys}

Monimuotoisuudella tarkoitetaan pellossa elävien, siitä ravintonsa saavien tai siellä tavattavien eläin-, kasvi-, hyönteis- ja mikrobistolajien moninaisuutta. Pellon monimuotoisuuteen kuuluu myös viljelykasvien geneettinen ja lajimääräinen monimuotoisuus. Tapa jolla pellon monimuotoisuutta hoidetaan, vaikuttaa pellon yksisoluisista organismeista lähtien aina maisemaan, maaseudun elinvoimaisuuteen ja maataloustuotteiden kauppaan saakka.

Maaperäeläinten ja mikrobien moninaisuudella voi olla suora yhteys esimerkiksi kasvien kilpailuun ja kasvuun (Bonkowski \& Roy 2005). Siten maaperän monimuotoisuuden ylläpito on oleellinen osa ihmisen ja maanpäällisen ekosysteemin toimintaa ja olemassaoloa (Römbke ym. 2005). Viljely- ja rikkakasvien monimuotoisuus puolestaan vaikuttaa maaperän hyvinvointiin (Russell 2002, Morgan ym. 2005) ja lukuisten pellossa elävien tai siitä ravintonsa saavien seuralaiseliöstöjen elinmahdollisuuksiin (Bellinder ym. 2004, Thorbek \& Topping 2005) sekä maiseman luonteeseen. Kun kasvustossa on runsas eliölajien monimuotoisuus, ei mikään yksittäinen laji saa yliotetta lisääntymällä liikaa. Parhaassa tapauksessa viljelykasvien tuholaistuhot voivat vähentyä. Esimerkiksi Englannissa lintujen pääsyn estäminen maissipeltoon johti tuhohyönteisten määrän lisääntymiseen (Tremblay ym. 2001). Monimuotoisuutta ylläpitämällä onkin mahdollista vähentää mm. torjunta-aineiden käyttöä (Lenteren 1998). Viljelijän talouteen monimuotoisuudella on riskejä ja katastrofeja pienentävä vaikutus (Koundouri 2004), koska tavallisesti tuho kohdistuu vain yhteen kasvilajiin ja siten sen merkitys viljelijän kokonaistaloudesta pienenee.

Vain eliölajien monimuotoisuuden ylläpidolla voidaankin turvata peltoekosysteemin tasapainoinen toimivuus myös tulevaisuudessa. Monimuotoisuus on myös apuna, kun viljelyn riippuvuutta ulkopuolisista panoksista kuten torjunta-aineista ja lannoitteista pyritään vähentämään. Pellon monimuotoisuuden vaaliminen on viljelijän edun mukaista, se on elintärkeää koko maatalouden säilyvyydelle sekä yhteiskunnallisesti mitä hyväksyttävintä.

\section{Viljelytekniikan vaikutus pellon monimuotoisuuteen}

Maatalouden intensiteetin lisääntymistä ja laidunnuksen vähentymistä (Smith \& Bruun 2002; Wolff ym. 2001) pidetään yleensä syynä monimuotoisuuden heikkenemiseen. Englannissa ja Ruotsissa peltoalueilla esiintyvien lintujen määrissä on havaittu selvää vähenemistä viimeisten 20 - 30 vuoden aikana (Peach ym. 2004, Smith \& Bruun 2002). Tanskassa muutokset eivät ole olleet niin suuria (Fox 2004). Pölyttäjistä erityisesti kimalaisten määrän havaittiin vähentyneen Englannissa jo vuosikymmeniä sitten (Williams 1982). Saksassa tehdyssä tutkimuksessa havaittiin, että viljelykasvilajiston määrä oli vähäisempi alueilla joissa maisemarakenne oli yksinkertainen verrattuna monimuotoiseen maisemaan. Myös runsaalla typen käytöllä, korkeilla satomäärillä ja erikoistumisella yksivuotisiin viljelykasveihin todettiin olevan yhteyttä yksinkertaiseen maisemarakenteeseen (Roschewitz ym. 2005). Useat teollistuneissa maissa tapahtuneet muutokset ovat saattaneet jäädä huomioimatta, koska vuosia kestäneitä seurantatutkimuksia on vähän eikä monimuotoisuuteen osattu aikoinaan kiinnittää huomiota. Kehitysmaista saadaan tietoa parhaillaan tapahtuvasta maatalouden tehostumisesta. Esimerkiksi Intiassa on perinteisesti viljeltävien kasvilajien määrä vähentynyt sitä mukaa kuin taloudellisemmin kannattavien kasvien kuten humalan, perunan ja herneen viljely on lisääntynyt (Kuniyal ym. 2004).

Useissa tutkimuksissa on voitu osoittaa, että menetelmät, joita nykyaikaisessa maataloudessa käytetään, vaikuttavat eliöiden esiintymiseen. Eri lähteiden mukaan voidaan erottaa ainakin neljä tekijää, joilla on havaittu olevan vaikutusta monimuotoisuuteen.

1) Torjuta-aineiden vähentäminen. Tämä on lisännyt muun muassa rikkakasvien laji- ja yksilömäärää (Hyvönen \& Salonen 2002) sekä lintujen määrää (Moreby \& Southway 1999) jättämällä sopivat ravintokasvit peltoon. 
2) Kyntämisen sijaan kevytmuokkaus. Lähes kolmekymmentä vuotta kestäneessä muokkauskokeessa kevytmuokkaus lisäsi rikkakasvien lajimäärää mutta ei vaikuttanut rikkojen lukumäärään (Mayor \& Maillard 1995).

3) Typpilannoituksen vähentäminen. Typpilannoituksen vähentäminen voi edistää esimerkiksi mikrobien monimuotoisuutta (Morgan ym. 2005).

4) Viljelykierto ja viljelykasvilajiston lisääminen. Viljelykierrot lisäsivät rikkasiementen määrää ja lajistoa (Bellinder ym. 2004) sekä maassa elävien mikrobien lajirunsautta (Lupwayi ym. 1998). Viljelykasvilajiston monimuotoisuus oli pysyvien turvapaikkojen lisäksi tärkein tekijä pellolla esiintyvän hämähäkin (Erigone atra) lisääntymiselle simulaatiotutkimuksessa (Thorbek \& Topping 2005). Viljelykasvien lajimäärällä ja valinnalla voitiin myös vaikuttaa pellolla ruokailevien lintujen määrään (Henderson ym. 2004). Viljelykasvilajiston monipuolisuuden lisäksi tai jopa sitä tärkeämmäksi todettiin kasvilajien kemiallisen koostumuksen vaikutus maan ravinnekiertoon ja kasvukykyyn. Tutkimuskohteena oli 50 tilaa Intiassa alueella, jota on viljelty yli 4000 vuoden ajan (Russell 2002).

Luonnonmukaisessa ja integroidussa viljelyssä toteutetaan kohtien $1-4$ toimenpiteitä. Niillä viljelyksillä onkin lajikirjo ollut usein tavanomaisesti viljeltyjä peltoja suurempi (Hyvönen \& Salonen 2002, Rydberg \& Milberg 2002, Wolff ym. 2001), mutta ei yksiselitteisesti aina (Weibull ym. 2003). Luonnonmukaisen maatalouden vaikutus monimuotoisuuteen saattaa riippua ympäristöstä, jossa tila sijaitsee. Mitä tehokkaampaa maatalous on tilan ulkopuolella, sitä edullisempi vaikutus luonnonmukaisella viljelyllä on (Bengtsson ym. 2005).

\section{Erikoiskasvit pellon monimuotoisuuden edistämisessä}

Maatalouden ympäristötukiehdoissa monimuotoisuuden perusedellytykset kuten torjunta-aineiden ja typpilannoituksen vähentäminen sekä kevytmuokkauksen suosiminen ovat jo kirjattuina. Vähemmälle huomiolle on jäänyt viljelykiertojen ja viljelykasvilajiston monimuotoisuuden edistäminen. Tämä saattaa johtua siitä, että vaihtoehtoisten peltoerikoiskasvien määrä oli vielä muutama vuosi sitten rajoitettu. Peltoerikoiskasvien kuten öljykasvien (öljypellava, kitupellava), viljojen tyyppisten kasvien (tattari, speltti), siemenmausteiden (kumina, muut siemenmausteet) sekä kuitu- ja energiakasvien (ruokohelpi, kuitupellava, hamppu, kuitunokkonen) yhteispinta-ala on noussut noin 300 hehtaarista (vuonna 1995) lähes 28000 hehtaariin (vuonna 2005) (Tike 2005). Pinta-alan nousun myötä erikoiskasveja kasvaa jo tuhansien viljelijöiden pellolla. Useiden kasvien kohdalla markkinat sallisivat viljelyn edelleen lisääntyvän.

Peltoerikoiskasvien käyttökelpoisuus monimuotoisuuden edistämisessä perustuu siihen, että ne ovat yleensä kaksisirkkaisia ja/tai monivuotisia. Tarkastelemalla nykyistä pellonkäyttöä havaitaan, että valtaosalla kasvaa yksisirkkaisia kevätkylvöisiä viljoja. Esimerkiksi Varsinais-Suomessa vuonna 2003 vajaat $60 \%$ peltoalasta oli kevätkylvöisiä viljoja; 11,5\% kaksisirkkaisia (öljykasvit, peruna, sokerijuurikas, palkokasvit), $10 \%$ kesantoa, $9 \%$ laidunta ja nurmea ja 8,5\% syyskylvöisiä viljoja. Kaksisirkkaisista vajaalla 5\%:1la peltoalasta kasvaa pölyttäjiä suosivia kasveja. Tilojen välillä pellonkäytössä on suuria eroja erikoistumissuunnasta riippuen. On tiloja, jotka ovat erikoistuneet pelkästään viljanviljelyyn (Tike 2005).

MTT:ssä vuonna 2003 alkaneessa MONIKASVI-tutkimuksessa tuotetaan monitieteellisesti tietoa erikoiskasvien mahdollisuuksista peltoluonnon monimuotoisuuden lisäämisestä. Tutkimuksen tavoitteet ovat 1) Tuottaa tietoa kahdeksan valitun erikoiskasvin (kinua, kitupellava, kumina, morsinko, nokkonen, ruokohelpi, tattari ja öljypellava) monimuotoisuuteen vaikuttavaista ominaisuuksista sekä kasvien viljelyn mikroympäristön monimuotoisuudesta. Valituista kasveista neljä on yksivuotista ja neljä kaksi- tai monivuotista. 2) Laskea valittujen erikoiskasvien viljelyn kannattavuus; 3) Selvittää viljelijöiden käsityksiä ja halukkuutta ryhtyä erikoiskasviviljelijäksi; 4) Luoda erikoiskasveille monimuotoisuusarvo, jonka perusteella ne voidaan asettaa järjestykseen. Arvon avulla voidaan niille antaa tehtävä, funktio, jossa kasvit erityisen hyvin monimuotoistavat peltoa. 5) Kehittää tiloille sopivaa atk-pohjaista menetelmää, jolla viljelykasvit voidaan sijoittaa peltolohkoille monimuotoisuuden lisäämiseksi ja ravinteiden huuhtoutumisriskin vähentämiseksi. Monikasviin kuuluvia osatutkimuksia on esitetty yksityiskohtaisemmin Maataloustieteen päivien muissa esitelmissä (Hakala \& Keskitalo 2006; Ikonen \& Huitu 2006; Palojärvi ym. 2006, Vuorio ym. 2006). Monikasvi-hanke kuuluu LUMOpelto-projektiin, joka 
on osa maa- ja metsätalousministeriön rahoittamaa Monimuotoisuuden tutkimusohjelmaa (MOSSE).

Erikoiskasvit ovat useimmille viljelijöille tuntemattomia ja siksi niitä voidaan kutsua myös tilan uusiksi viljelykasveiksi riippumatta siitä, miten paljon kasveja muualla viljellään. Uuden kasvin viljelyn aloittamista voidaan verrata innovaation omaksumiseen (Janick ym. 1996), mitä varten viljelijä tarvitsee taustatietoa päätöksenteon tueksi (Kuva 1). Monikasvi-tutkimuksessa tuotetaan tietoa neljään kuvan kuudesta osa-alueesta.

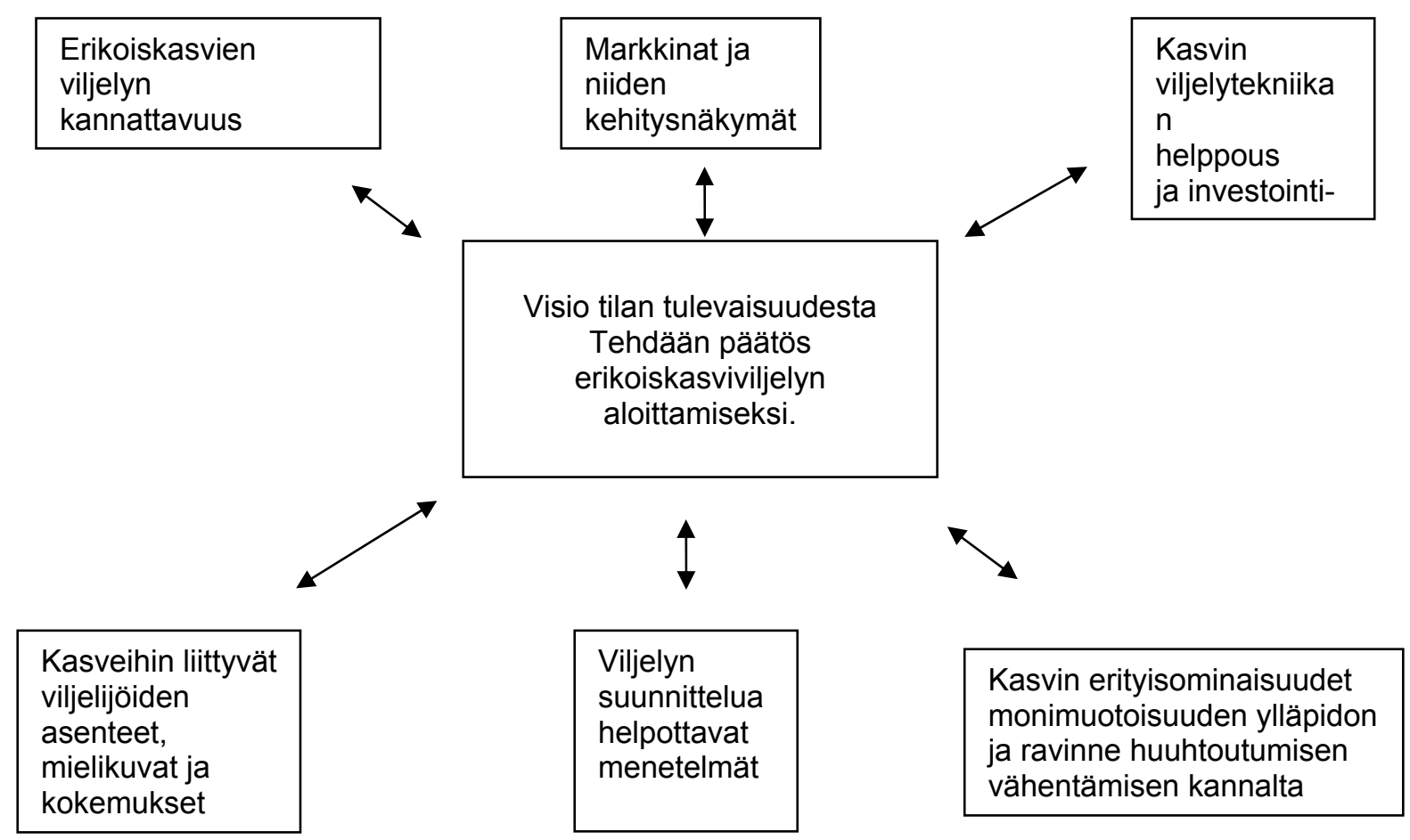

Kuva 1. Erikoiskasvinviljelyn aloittamispäätökseen vaikuttavia tekijöitä.

\section{Monikasvin eri osatutkimukset}

\section{Erikoiskasvien vaikutus pellon monimuotoisuuteen}

Viljelykasvien monimuotoisuuteen liittyvien ominaisuuksien tutkiminen on jäänyt vähemmälle huomiolle kuin luonnonkasvien tai esim. pellon reunan tai suojakaistojen eliöyhteisöjen monimuotoisuus. Syynä on todennäköisesti se, että vasta viime vuosina pellon monimuotoisuuteen on alettu kiinnittää huomiota ja päähuomio on ollut sadonmuodostukseen liittyvän tiedon tuottamisesta, tavoitteena suurimmat mahdolliset sadot edullisimmilla menetelmillä. Myös kasvien viljely itsessään ajatellaan joskus olevan pelkästään monimuotoisuutta vähentävää toimintaa. Monimuotoisuuteen vaikuttamista on lähestytty teknisin keinoin. Sen sijaan viljelykasvien biologisten ominaisuuksien hyödyntämisestä monimuotoisuuden lisäämiseksi on vähän tutkimustietoa saatavilla.

Tämän osion tavoitteena on tuottaa tietoa neljän kaksisirkkaisen (tattari, kitupellava, öljypellava, kinua) ja neljä kaksi- tai monivuotisen (kumina, morsinko, nokkonen, ruokohelpi) erikoiskasvin monimuotoisuuteen vaikuttavista biologisista ominaisuuksista sekä kasvien vaikutuksista niiden mikroympäristön monimuotoisuuteen. Mitattavia tekijöitä ovat juuristomikrobien yhteisörakenne ja kasvin kasvun kannalta hyödyllisten mikrobien esiintyminen (ks Palojärvi ym 2006); juurimassan kehitysnopeus; juurten ravinnekoostumus (ks Hakala \& Keskitalo 2006) ja liukoisten fenolien määrä; maanpäällisen peittävyyden ja biomassan kehitysnopeus; maanpäällisen biomassan ravinnekoostumus ja liukoisten fenolien määrä; ravinteiden allokointi korjattavaan ja maan päälle jäävään satoon; seuralaisrikkakasvien määrä ja biomassan koostumus; kukinta ja siitepölyn lentoaika sekä pölyttävien hyönteisten määrä. 
Tuotetun tiedon avulla laaditaan monimuotoisuusarvo, jonka perusteella kasvit voidaan asettaa järjestykseen monimuotoisuuteen vaikuttavien ominaisuuksiensa perusteella. Lisäksi tietoa hyödynnetään MonikasviGIS menetelmän kehittämisessä. On mahdollista, että monimuotoisuuden vähäisyydestä kärsiville pelloille annetaan tulevaisuudessa viljelyohjeistuksia. Erikoiskasvien käyttö viljelykasvilajiston lisäämisessä ja osana viljelykiertoa ovat silloin varteenotettavia mahdollisuuksia.

\section{Viljelyn kannattavuus}

Kolmen valitun erikoiskasvin (öljypellava, tattari, kumina) taloutta tilatasolla verrataan vastaavissa tuotanto-olosuhteissa harjoitettavaan viljantuotantoon. Tarkastelu tehdään tilamallein, joiden avulla voidaan kuvata tuotantoa, josta on saatavissa vähän tilastoitua tuotanto- tai taloustietoa. Mallien rakentamisessa käytetään pohjana MTT Taloustutkimuksen viljatilamalleja, joita täydennetään ja muokataan tutkittavista kasveista tämän hankkeen kautta saatavilla biologis-teknisillä tiedoilla.

\section{Asenteiden merkitys erikoiskasviviljelyssä}

Varsinaisen päätöksen tilansa toiminnasta tekee viimekädessä viljelijä. Päätöksen takana vaikuttavat useat erilaiset tekijät kuten viljelijän taloudellinen tilanne, aikaisemmat viljelykokemukset sekä tulevaisuuden päämäärät. Merkittävänä tekijänä viljelypäätöksen tekemisessä on myös viljelijän oma asenne ja näkemys valittavasta kasvista ja kasvin sopivuudesta oman tilansa toimintaan.

Tässä tutkimusosiossa (ks Vuorio ym. 2006) selvitetään viljelijöiden kokemuksia ja näkemyksiä erikoiskasveista. Tutkimuksen toteutustapana on internetkysely, joka on suunnattu sekä erikoiskasveja viljelleille että niitä viljelemättömille. Tutkimuskysymystä lähestytään innovaation omaksumisteorian kautta. Osioin tavoitteena on kartoittaa, ketkä erikoiskasviviljelyyn ovat lähteneet, mitkä tekijät viljelypäätökseen ovat vaikuttaneet, millaiseksi vaihtoehdoksi viljelijät mieltävät erikoiskasviviljelyn tulevaisuudessa sekä millä keinoin erikoiskasviviljelyä on mahdollista jatkossa lisätä.

\section{Erikoiskasvien viljelyn suunnitteluväline monimuotoisuuden lisäämiseksi}

MonikasviGIS kehitetään paikkatietopohjaista menetelmää (ks Ikonen \& Huitu 2006), jolla voidaan mallintaa yksittäisen tilan sisällä monimuotoisuuden ja fosforikuormituspotentiaalin spatiaalinen vaihtelu ja antaa mallinnukseen perustuvia viljelysuosituksia peltolohkoille, kun tunnetaan eri viljelykasvien vaikutus pellon monimuotoisuuteen ja fosforin sitomiskyky. Menetelmällä voidaan luoda useita vaihtoehtoisia viljelysuosituksia riippuen siitä, millaiset painokertoimet viljelykasvin valinnassa annetaan monimuotoisuuden parantamiselle ja toisaalta fosforikuormituksen vähentämiselle.

\section{Tulokset ja tulosten tarkastelu}

Erikoiskasvien biologisissa ominaisuuksissa on eroja kaikkien tutkittujen parametrien suhteen. Ravinnetutkimukset osoittivat, että maahan jäävissä juurissa oli fosforia eniten monivuotisilla kasveilla, koska ne tuottivat tehokkaasti juurimassaa. Siten monivuotisten kasvien viljely olisi fosforin huuhtoutumisriskin vähentämisen kannalta suotavaa. Monivuotiset ja runsaasti juurimassaa tuottavat kasvit ovat myös potentiaalisia maaperän eroosion estäjiä. Sen lisäksi neliömetriä kohti laskettuna nämä kasvit tuottivat runsaasti fenoleita, joilla tiedetään olevan allelopaattisia vaikutuksia. Maanpäällisen biomassan ja siten mahdollisen humuksen tuotossa monivuotiset olivat yksivuotisia tehokkaampia. Sadon mukana pellosta poistuu eniten typpeä ja fosforia etenkin yksivuotisten (öljypellava, tattari ja kitupellava) siemensadossa, mutta myös runsasbiomassaisen ruokohelven sekä nokkosen varsisadossa. Eniten typpeä ja fosforia poistuu, kun kasvista korjataan sekä siemenet että varret (hamppu ja öljypellava). Kumina ja morsinko kaksivuotisina kasveina eivät olleet tässä vertailussa mukana (ks. Hakala \& Keskitalo 2006).

Erikoiskasvien vaikutuksessa kasvien mikroympäristöön on myös havaittavissa eroja. Juurien mikrobiyhteisöjen monimuotoisuus määritettiin vertaamalla mikrobien soluseinän fosfolipidirasvahappokoostumusta. Kuminan, morsingon ja kinuan mikrobiyhteisöt olivat ohraa (verranne) monimuotoisempia, kun taas tattari, kitupellavan ja öljypellavan mikrobiyhteisöt eivät poikenneet ohrasta (ks. Palojärvi ym. 2006). Erikoiskasvien joukossa esiintyvien rikkakasvien lajimäärä ja paino laskettiin kasvukauden eri vaiheissa. Korjuuvaiheessa tehdyssä määrityksessä rikkojen painot olivat yksivuotisilla erikoiskasveilla yleensä ohraa (verranne) korkeammat ja kaksi tai monivuotisilla kasveilla timoteitä 
(verranne) pienemmät. Lajimääräisesti eroja ei kyseisenä koevuotena havaittu, mutta kokeita jatketaan edelleen. Pölyttäjiä houkuttelivat erityisesti kukkivat kaksisirkkaiset kuten tattari, kumina ja morsinko, mutta myös muut erikoiskasvit tai niiden kukkivat rikkakasvit olivat houkuttelevia.

Viljelijäkysely herätti laajaa mielenkiintoa viljelijäväestössä. Kyselyn perusteella voidaan havaita, että moni viljelijä kokee erikoiskasvit mahdollisena vaihtoehtona tilantoiminnan jatkumiselle tai toiminnan monipuolistamiselle. Kiinnostavia kasveja ovat muun muassa kumina ja ruokohelpi, mutta mielenkiintoa on myös öljy- ja kuitupellavan, tattarin ja speltin viljelyyn. Erikoiskasviviljelijät ovat pääosin kasvinviljelyyn keskittyneitä viljelijöitä ja heistä tavallista useampi on luomuviljelijä. Tutkimuksen mukaan erikoiskasviviljelyn omaksumisen taustalla vaikuttavat yleisesti taloudelliset hyötynäkökulmat, mutta myös kasvien muilla ominaisuuksilla on viljelijöille merkitystä. Tällaisia ovat $\mathrm{mm}$. kasvien vaikutukset maaperän hyvinvoinnille, usko erikoiskasvien menekkiin tulevaisuudessa sekä kasvien myönteiset vaikutukset tilan imagolle. Erikoiskasviviljely näyttäisi sopivan viljelijöille, jotka ovat ennakkoluulottomampia kokeilemaan uusia vaihtoehtoja tilallaan ja näin ollen halukkaampia riskinottoon. (ks. Vuorio ym. 2006).

MonikasviGIS -pilottimalli on esitetty Kuvassa 2. Pilottialueeksi valittiin MTT:n Lintupajun tila. Pilottivaiheen kahdelle kriteerille, monimuotoisuudelle ja fosforikuormituspotentiaalille perustuva viljelysuositusmalli ei luonnollisestikaan sisällä kaikkia niitä tekijöitä, jotka todellisessa viljelykasvin valintatilanteessa ovat oleellisia. Esimerkiksi kasvien monimuotoisuusvaikutus laskettiin käyttäen tutkimuksessa saatuja tuloksia juuristomikrobien (Palojärvi ym. 2006) ja pölyttäjähyönteisten lajirunsaudesta. Pilottimallin ensivaiheessa haluttiin sijoittaa kaikki tutkimuksessa olevat kasvit ainakin yhteen peltolohkoon, vaikka todellisessa viljelyssä näin tuskin on. Menetelmän kehittelyn alkuvaiheessa on kuitenkin ollut tarkoituksenmukaista pitää malli todellista tilannetta yksinkertaisempana, jotta tekniikoiden ja menetelmien kehittäminen on pysynyt selkeämpänä (ks Ikonen \& Huitu 2006).

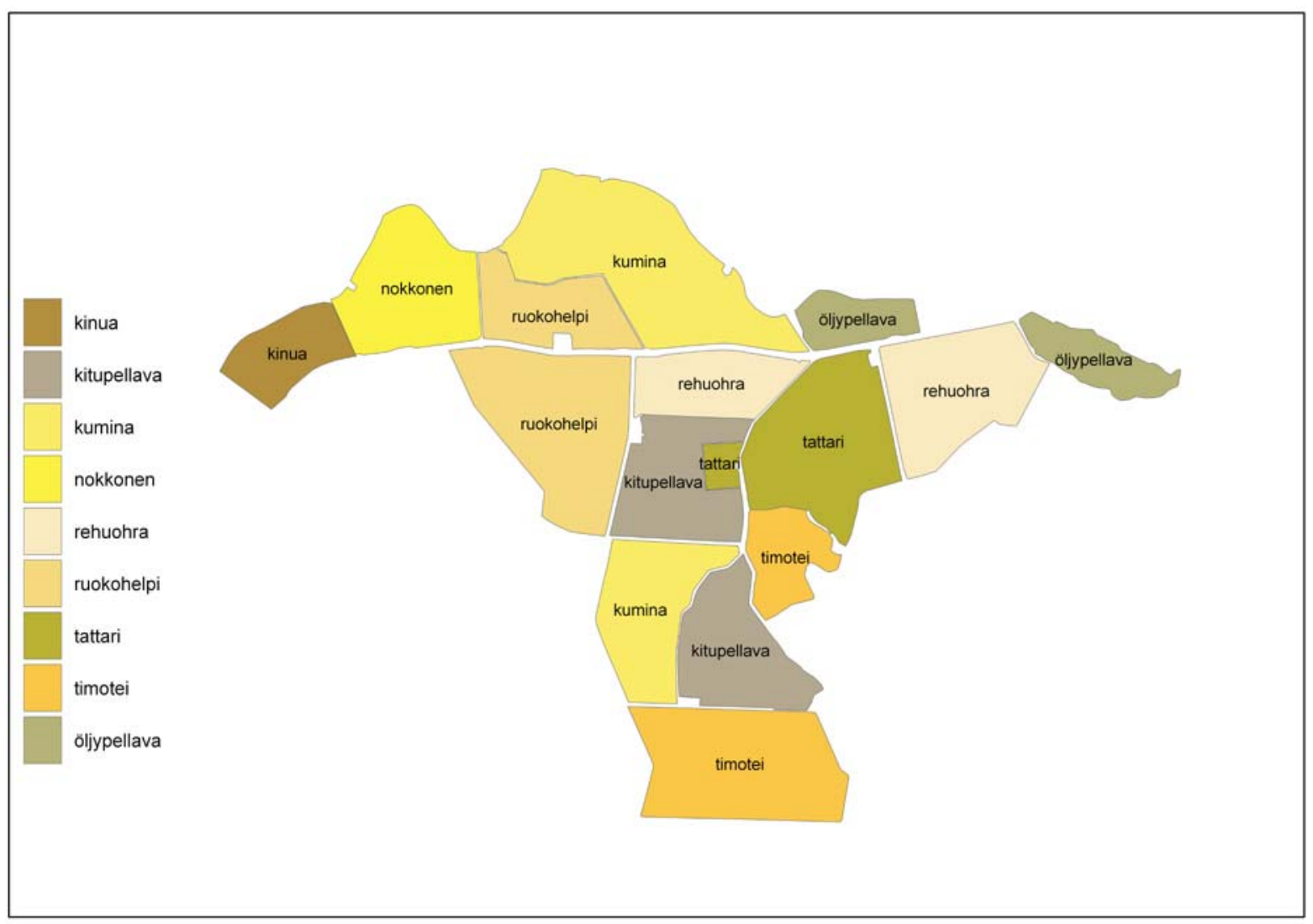

Kuva 2. Paikkatietomenetelmiin perustuva viljelysuositus MTT Lintupajun peltolohkoille. Suositus perustuu tilan viljelyhistoriatiedoista (mm. aiemmat lohkorajat, viljelykasvit) numeerisena indeksinä lasketulle lohkojen nykyisen monimuotoisuustason ennusteelle. Nykytilan ennusteen perusteella on lohkoille annettu viljelysuositukset siten, että suotuisimmin monimuotoisuuteen vaikuttavia kasvilajeja suositellaan viljeltäviksi lohkoilla, joissa nykyisen monimuotoisuustason ennustetaan olevan alhaisin (Ikonen \& Huitu 2006). 


\section{Johtopäätökset}

Viljelykasvilajiston monipuolistamiseen on jatkossa kiinnitettävä enemmän huomiota. Vaikka viljelykierrot olivat aikaisemmin tärkeä osa viljelykäytäntöä, eivät ne enää sitä ole. Tämä voidaan nähdä myös tilastoista, joiden mukaan suurimmalla osalla Etelä-Suomen pelloista viljellään kevätkylvöisiä viljoja ja usein vielä monokulttuurissa. Samanaikaisesti uudeksi huoleksi on noussut peltojen monimuotoisuuden tilan heikkeneminen ravinnehuuhtoutumisten lisäksi. Maatalouden ympäristötukeen on kirjattu monimuotoisuuden kannalta keskeisiä viljelytoimenpiteitä kuten torjunta-aineiden vähentäminen, typen käytön rajoittaminen ja kevytmuokkauksen suosiminen. Sen sijaan viljelykiertojen tärkeys on jäänyt vähemmälle huomiolle. Erikoiskasvien viljely viljelykasvilajiston monipuolistamisessa ja osana viljelykiertoa on ajatuksellisesti uusi, mutta perusteltu.

1) Erikoiskasvit sisältävät suuren ominaisuuksien kirjon, mikä on hyvä lähtökohta pellon monimuotoisuuden edistämisessä. Perusteltua on siis ajatella, että erikoiskasveja viljelemällä pellon monimuotoisuutta voidaan ylläpitää. On myös tärkeä havaita, että itse kasvi ja kasvin biologiset ja kemialliset ominaisuudet ovat sellaisia, joita voidaan hyödyntää monimuotoisuuden lisäämisessä. Tähän saakka tutkimuskohdetta on lähestytty pelkästään teknologisin keinoin.

2) Viljely on Suomessa laajentunut lähes satakertaisesti kymmenen viime vuoden aikana ja jo nyt erikoiskasveja viljellään tuhansilla tiloilla. Viljelijäkyselyn perusteella viljelyn laajeneminen jatkossa on hyvinkin todennäköistä markkinoiden sallimissa rajoissa.

3) Erikoiskasvien viljely on maataloutta ja maaseudun yritystoimintaa aktivoivaa toimintaa. Erikoiskasvista saadaan hyötyaineita, joiden jatkojalostus tai osa siitä sopii maaseudulla toimiviin yrityksiin. Vaikka kasveja viljellään monimuotoisuuden ylläpidon takia, voitaisiin sato kuitenkin korjata ja myydä. Muissa monimuotoisuuden ylläpitoehdotuksissa kasvien tuotteita ei saa hyödyntää. Erikoiskasvien viljelyllä pellon monimuotoisuuden lisäämiseksi olisikin mahdollista monimuotoistaa myös maaseudun yritystoimintaa. Se tietenkin vaatii eri sektorien kuten jatkojalostuksen, markkinoinnin ja ohjauskeinojen yhteistoimintaa ja kehittämistä.

4) Maataloutemme on jatkossakin riippuvainen viljelytuista, joita kohtaa esitetään yhä kovenevaa kritiikkiä. Peltojen monimuotoisuuden ylläpito on kansallisesti mitä tärkeintä. Kun vielä monimuotoisuutta ylläpidetään kuluttajaa kiinnostavien ja arvostavien 'vihreitä' hyötyaineita tuottavien erikoiskasvien avulla, saanee tukien maksu suurenkin yleisön hyväksynnän.

5) Peltojemme monimuotoisuuden tulevaisuudessa on kokonaisuutena kysymys siitä, miten maatalouttamme harjoitetaan. Onko laajenevien ja yksipuolistuvien tilojen visio ainoa mahdollisuus? Ympäristön monimuotoisuuden kannalta näyttää siltä, että monimuotoista, usean viljelykasvin maataloutta harjoittavilla tiloilla on erityinen tilaus tulevaisuudessa.

Vaikka tutkimukset ovat kesken, voidaan todeta että kaksisirkkaisten ja monivuotisten erikoiskasvien viljelyn lisääminen on pellon monimuotoisuuden kannalta oleellista. Se, miten eri kasveilla voidaan täsmällisemmin vaikuttaa eri eliöiden monimuotoisuuteen ja minkälaisissa viljelykierroissa niitä tulisi viljellä, tarvitsee vielä lisätutkimuksia, joita Monikasvissakin tehdään. Tutkimustietoa tulee saada lisää myös eri eliöiden laji- ja populaatiomäärien muutoksista, jotta viljelytoimenpiteet voitaisiin kohdistaa ainakin uhanalaisten eliöiden suojelemiseksi. Erikoiskasvien viljely monimuotoisuuden lisäksi myös ravinnehuuhtoutumisriskin vähentämiseksi tekee kokonaisuuden hallitsemisen vieläkin haasteellisemmaksi. Toisaalta monet tekijät, jotka estävät ravinteiden huuhtoutumista ovat niitä, joilla muun muassa maaperän monimuotoisuutta ja kasvukykyä ylläpidetään. Onkin tärkeää, että menetelmiä monimuotoisuuden suunnittelussa ja ravinteiden vähentämiseksi kehitetään. Tulevaisuudessa on hyvinkin mahdollista, että voimme erikoiskasvien ominaisuuksiin ja pellon paikkatietoihin perustuen laatia kasvilajiston laajentamisesta ja viljelykierroista täsmäsuosituksia 'lääkkeeksi' pellon monimuotoisuuden edistämiseksi ja ravinnehuuhtoutumisten vähentämiseksi.

\section{Kirjallisuus}

Bellinder, R.R., Dillard, H.R. \& Shah, D.A. 2004. Weed seedbank community responses to crop rotation schemes. Crop Protection 23: 95-101.

Bengtsson, J., Ahnström, J. \& Weibull, A-C. 2005. The effects of organic agriculture on biodiversity and abundance: a meta-analysis. Journal of Applied Ecology 42: 261-269. 
Bonkowski, M. \& Roy, J. 2005. Soil microbial diversity and soil functioning affect competition among grasses in experimental microcosms. Oceologia 143: 232-240.

Fox, A.D. 2004. Has Danish agriculture maintained farmland bird populations? Journal of Applied Ecology 41: 427439.

Hakala, K. \& Keskitalo, M. 2006. Erikoiskasvien juuriston ja ravinteiden allokoinnin monimuotoisuus. Maataloustieteen päivät 2006, Viikki, Helsinki. www.smtp.fi.

Henderson, I.G., Vickery, J.A. \& Carter, N. 2004. The use of winter bird crops by farmland birds in lowland England. Biological Conservation 118: 21-32.

Hyvönen, T. \& Salonen, J. 2002. Weed species diversity and community composition in cropping practices at two intensity levels - a six-year experiment. Plant ecology 154: 73-81.

Ikonen, A. \& Huitu, H. 2006. MonikasviGIS. Paikkatietopohjainen menetelmä erikoiskasvien sijoitteluun. Maataloustieteen päivät 2006, Viikki, Helsinki. www.smtp.fi.

Janick, J., Blase, M.G., Johnson, D.L., Joliff, G.D. \& Myers, R.L. 1996. Diversifying U.S. crop production. Eds Janick, J. In Progress in new crops: Proceedings of the third national symposium, Indianapolis, Indiana USA 22-25 October 1996 pp 98-109.

Koundouri, P. 2004. The role of risk properties and farm risk aversion on crop diversity conservation. Eds. Falco \& Perrings. In New Horizons in Environment Economics Econometrics informing natural resources management: selected empirical analyses 2004: 231-246.

Kuniyal, J.C., Vishvakarma, S.C.R. \& Singh, G.S. 2004. Changing crop biodiversity and resource use efficiency of traditional versus introduced crops in the cold desert of the northwestern Indian Himalaya: a case of the Lahaul valley. Biodiversity and Conservation 13: 1271-1304.

Lenteren, J.C.van. 1998. Sustainable and safe crop protection: a reality? Mededelingen Faculteit Landbouwkundige en Toegepaste Biologische Wetenschappen, Universiteit Gent 1998: 63: 409-414.

Lupwayi, N.Z., Rice, W.A. \& Clayton, G.W. 1998. Soil microbial diversity and community structure under wheat as influenced by tillage and crop rotation. Soil Biol. Biochem 30: 1733-1741.

Mayor, J. Ph. \& Maillard, A. 1995. Results of an over 20 year no-tillage trial at Changins. IV Seed stock and weed control. Revue Suisse d'Agriculture (Switzerland) 27:229-236.

Moreby, S.J. \& Southway, S.E. 1999. Influence of autumn applied herbicides on summer and autumn food available to birds in winter wheat fields in southern England. Agriculture, Ecosystems and Environment 72: 285-297.

Morgan, J.A.W., Bending, G.D. \& White, P.J. 2005. Biological costs and benefits to plant-microbe interactions in the rhizozphere. Journal of Experimental Botany 56: 1729-1739.

Palojärvi, A., Kaipainen, S., Peura, S. \& Eriksson, C. 2006. Erikoiskasveilla voidaan vaikuttaa peltomaan monimuotoisuuteen. Maataloustieteen päivät 2006, Viikki, Helsinki. www.smtp.fi.

Peach, W.J., Denny, M., Cotton, P.A., Hill, I.F., Gruar, D., Barrit, D., Impey, A. \& Mallord, J. 2004. Habitat selection by song thrushes in stable and declining farmland populations. Journal of Applied Ecology 41: 275-293. Roschewitz, I., Thies, C. Tscharntke, T. 2005. Are landscape complexity and farm specialisation related to land use intensity of annual fields? Agriculture, Ecosystems and Environment 105: 87-99.

Russell, A.E. 2002. Relationships between crop-species diversity and soil characteristics in southwest Indian agroecosystems. Agriculture, Ecosystems and Environment 92: 235-249.

Römbke, J., Breure, A.M., Muldel, C. \& Rutgers, M. 2005. Legislation and ecological quality assessment of soil: implementation of ecological indication systems in Europe. Ecotoxicology and Environmental Safety 62: 201-210. Rydberg, N.T. \& Milberg, P. 2002. A Survey of weeds in organic farming in Sweden. Biological Agriculture and Horticulture 18: 175-185.

Smith, H.G. \& Bruun, M. 2002. The effect of pasture on starling (Sturnus vulgaris) breeding success and population density in a heterogeneous agricultural landscape in southern Sweden. Agriculture, Ecosystems and Environment 92: 107-114.

Thorbek, P. \& Topping, C.J. 2005. The influence of landscape diversity and heterogenity on spatial dynamics of agrobiont linyphiid spiders: An individual-based model. BioControl 50: 1-33.

Tike, Maa- ja metsätalousministeriö, Tietopalvelukeskus. 2003 ja 2005.

Tremblay, A., Mineau, P. \& Stewart, R.K. 2001. Effects of bird predation on some pest insect populations in corn. Agriculture, Ecosystems and Environment 83: 143-152.

Vuorio, H., Soini, K. \& Ikonen, A. 2006. Kenestä on erikoiskasviviljelijäksi? Erikoiskasviviljelyn omaksujatyypit ja omaksumisen taustalla vaikuttavat tekijät. Maataloustieteen päivät 2006, Viikki, Helsinki. www.smtp.fi.

Weibull, A-C., Östman, Ö. \& Granqvist, Å. 2003. Species richness in agroecosystems: the effect of landscape, habitat and farm management. Biodiversity and Conservation 12: 1335-1355.

Williams, PH. 1982. The distribution and decline of Brittish bumblebees (Bombus Latr.). Journal of Apicultural Research 21: 236-245.

Wolff, A., Paul, J.P., Martin, J.L. \& Bretagnolle, V. 2001. The benefits of extensive agriculture to birds: the case of the little bustard. Journal of Applied Ecology 38:963-975. 